\section{EVIDENCE OBTAINED BY TORTURE}

The recent House of Lords decision in $A$ and Others $V$ Secretary of State for the Home Department (No. 2) (December $8,2005)$ has been hailed as a ringing endorsement of the international legal principle prohibiting torture and the evidentiary use of the fruits of torture as set forth under Article 15 of the Torture Convention and recognised into European law by Article 3 of the European Convention on Human Rights. The Lords decision allows persons certified and detained as terrorists under the Anti-Crime, Security and Terrorism Act 2001 to exclude the evidentiary use of statements obtained by official torture in foreign countries. The decision overruled a Court of Appeal decision, [2005] 1 WLR 414, that had upheld the powers of UK administrative tribunals and the Special Immigration Appeals Commission to receive evidence obtained by official torture in foreign countries without involvement of British authorities when reviewing the use of control orders under UK anti-terrorist legislation.

The ruling reaffirms an important principle of English common law that prohibits the admissibility of evidence obtained under torture and gives effect to the UK's international legal obligation under the Convention against Torture 1984 to exclude the use of any statements obtained by official torture. The case, however, raises important issues regarding the delicate balance to be struck between protecting fundamental human rights and adopting special legislation and measures to combat international terrorism. Moreover, the decision raises a substantial challenge to anti-terrorist efforts regarding the type of evidentiary procedure to be used by special tribunals in determining whether statements have been obtained by torture and thus admissible against alleged terrorists.

In the decision, Lord Bingham identified the main issue as being whether the special appeals tribunal established under section 25 of the 2001 anti-terrorist Act to hear appeals by persons certified and detained pursuant to sections 21-23 of the act was empowered to hear evidence which was or might have been obtained by official torture in a foreign country. Lord Bingham stated that the "principles of the common law, standing alone, compelled the exclusion of third party torture evidence as unreliable, unfair, offensive to ordinary standards of humanity and decency and incompatible with the principles which should animate a tribunal seeking to administer justice."

Regarding Britain's international legal obligations, he observed that '[i]t was common ground that the international prohibition of the use of torture enjoyed the enhanced status of a jus cogens or peremptory norm of general international law" which was "a norm from which no derogation was permitted and which could be modified only by a subsequent norm of general international law'. This norm had been codified by the 1984 United Nations Convention against Torture to which the United Kingdom

Articles
$\begin{aligned} & \text { Government and information - the limits of law's } \\ & \text { empire }\end{aligned}$
$\begin{aligned} & \text { The independence of the judiciary within a European } \\ & \text { context }\end{aligned}$
$\begin{aligned} & \text { News } \\ & \text { Articles (cont'd) }\end{aligned}$
$\begin{aligned} & \text { Natural disasters and the issue of responsibility for } \\ & \text { the victim states }\end{aligned}$
$\begin{aligned} & \text { The simplification of the election of certain German } \\ & \text { employee representatives }\end{aligned}$

was a party. Moreover, he noted that UK law was subject to the European Human Rights Convention "which itself took account of the all but universal consensus embodied in the Torture Convention." Therefore, based on the English common law and peremptory norms of international law, he held that the special administrative tribunals established under anti-terrorist legislation to hear appeals of terrorist control orders were not allowed to hear evidence that was or might have been procured by official torture in a foreign country.

The Home Secretary had accepted that existing UK law prohibited him from relying on evidence obtained by torture if it was inflicted by or with the consent of British authorities, but that the special powers created by section 25 of the 2001 Act empowered the special immigration tribunals to hear any evidence submitted by the Home Secretary, even if such evidence was procured, without official British assistance, by torture in a foreign country. According to the Home Secretary, the fact that evidence had or might have been obtained by torture inflicted by foreign officials without British assistance was relevant to its weight but did not render it inadmissible. Moreover, the Home Secretary suggested that, as a policy matter, he would not ordinarily "rely on, or present to the commission or the administrative court in relation to control orders, evidence which he knew or believed to have been obtained by a third country by torture." However, he argued that the admission of such evidence to the tribunals was not precluded by law, although its submission would generally be disfavoured as a matter of policy. The Home Secretary's undertaking in this regard was not a satisfactory safeguard for Lord Bingham who declared that "the central question was to be found not in government policy, which might change, but in law."

The Lords decision reaffirms the prohibition against torture as a fundamental norm of international law. Moreover, it clarifies the meaning of article 15 of the Torture Convention as prohibiting the admission into evidence, for any/civil or criminal state proceeding or enforcement action, statements obtained by official torture 
in a foreign country. Even under anti-terrorist legislation, states are not free to derogate from this prohibition in cases involving civil proceedings of deportation of terrorist suspects or for indefinite detention of suspected terrorists. The prohibition against the admissibility into evidence of all statements induced by official torture in both civil and criminal proceedings is now clearly recognised under UK law, and could potentially lead to other jurisdictions, especially those subject to the European Convention on Human Rights, adopting similar interpretations.

However, it should be noted that some jurisdictions that are parties to the Torture Convention, such as the United States, have taken a different approach to deciding whether to admit evidence that was procured by foreign torture. US courts adhere to Federal Rules of Evidence 403 which states that "relevant evidence may be excluded if its probative value is substantially outweighed by the danger of unfair prejudice, confusion of the issues, or misleading the jury." Moreover, the US Supreme Court has held that when US officials engage in conduct that "shocks the conscience", a US court must divest itself of jurisdiction over the case and dismiss the indictment. United States $V$ Toscanino 500 F.2d 267, 272 (2d Cir. 1974).

This has been interpreted as applying to episodes when US officials use torture to obtain statements from the accused or from witnesses to be used against the accused. United States v Yousef 327 F. 3d 56, 140 (2d. Cir. 2003). However, if US officials are not involved in the torture that procures the statements, then the evidence is potentially admissible if it satisfies the criteria of Rule 403 of the Evidence Code. For instance, the evidence would be admissible in either a criminal or civil proceeding if the statements have probative value that is not substantially outweighed by its prejudicial effect. Yousef at 140-141. The court would have discretion to admit the statements if it was convinced that the prejudicial effect of admitting such statements did not substantially outweigh its probative value. The admission of statements obtained from official torture in a foreign country would be decided based on the court's determination of its probative value weighed against its prejudicial effect. This is in stark contrast to the position under UK law, the European Convention on Human Rights, and Article 15 of the Torture Convention that requires such evidence to be inadmissible in a court of law. The US could be in potential breach of its obligations under the Torture Convention.

The House of Lords decision in $A$ and others will have important implications for how the war on terrorism will be fought in domestic courts and administrative tribunals. For instance, what type of evidential standard should a country adopt for its tribunal to apply when weighing the likelihood that statements offered against a suspected terrorist have been obtained by official torture? In his statement, Lord Bingham suggested that administrative tribunals should determine as a preliminary matter whether the statement was obtained from a country known or widely suspected of practising torture. If so, then the tribunal should not admit the statement unless the tribunal could be satisfied that there was no "real risk" that the statement was obtained by torture. This apparently would require the Home Secretary to prove to the tribunal on the balance of probabilities that the statement was not procured by official torture.

Lord Hope, in a concurring opinion, recognised that "a conventional approach to the burden of proof was inappropriate", and it would be unfair to expect the detainee to prove anything because he would not have access to sufficient information. However, he disagreed with Lord Bingham's "real risk" test by observing that Article 15's exclusionary rule only applied to a "statement that was established to have been made under torture." As an alternative, Lord Hope suggested that the test laid down by article 15 should require the tribunal to make "diligent inquiries into the sources that it was practicable to carry out" and on the balance of probabilities determine whether 'the information relied on by the Home Secretary was obtained under torture'. Rather than requiring the Home Secretary to prove that there was no "real risk", Lord Hope's approach would require the terrorist suspect to identify practicable sources of information to show that it was more likely than not that the Home Secretary had relied on information obtained by official torture.

Both of these approaches raise a number of concerns regarding practicality of identifying sources of torture and fairness to the terrorist suspect of proving the likelihood of official torture in a foreign country. Until these concerns are resolved, there will be continuing concern about the efficacy of the human rights protections for detainees and terrorist suspects and there will be uncertainty regarding the appropriate approach for law enforcement to follow in protecting society from the real risk of terrorism.

\section{Dr Kern Alexander}

Senior Research Fellow, Institute of Advanced Legal Studies, University of London 